\title{
Prevalence of head and neck Myofascial Pain Syndrome in a South American population
}

Prevalencia del síndrome de dolor miofascial de cabeza y cuello en una población Sudamericana

Prevalência da síndrome da dor miofascial de cabeça

e pescoço em uma população sul-americana

\section{Olga Lucía Giraldo Rivera ${ }^{1}$}

\begin{abstract}
Received: November $13^{\text {th }}, 2019$
Accepted: August $18^{\text {th }}, 2020$

Published: October $15^{\text {th }}, 2020$

How to cite this article:

Giraldo-Rivera OL. Prevalence of myofascial head and neck pain syndrome in a South American population. Revista Nacional de Odontología. (2020); 16(1), 1-13. doi: https://doi.org/10.16925/2357-4607.2020.01.11
\end{abstract}

Artículo de investigación. https://doi.org/10.16925/2357-4607.2020.01.11

1 Universidad de Antioquia, Medellín, Colombia.

Email: olga.giraldo@udea.edu.co.

ORCID: https://orcid.org/0000-0001-9581-9411 


\section{Abstract}

Objective: To diagnose the prevalence of Myofascial Pain Syndrome (MPS) with respect to sex, age, affected muscle, socioeconomic stratum, occupation and associated symptoms.

Methods: This is a descriptive, cross-sectional study of a convenience sample of 220 outpatients who attended the Faculty of Dentistry of the Universidad de Antioquia Medellín-Colombia, between September $30^{\text {th }}, 2015$ and September $7^{\text {th }}, 2017$. Interventions: not applicable. Main measure of results: Myofascial Pain Syndrome.

Results: $26.4 \%$ of our sample presented symtoms of MPS. More women than men were found to have MPS. The number of cases decreases with age. The most affected muscle is the trapezium, followed by the temporalis, and there are no significant differences in terms of socioeconomic stratum and occupation. The most frequently reported associated symptom is neck pain.

Conclusion: Because there is such a high prevalence, and on a global scale, we believe it is important to establish effective means of diagnosis and adequate measures for the prevention and treatment of this pathology.

Keywords: Myofascial Pain Syndrome, prevalence, trigger point.

\section{Resumen}

Objetivo: Diagnosticar la prevalencia del Síndrome de Dolor Miofascial (MPS) con respecto al sexo, edad, músculo afectado, estrato socioeconómico, ocupación y síntomas asociados.

Métodos: Se trata de un estudio descriptivo, transversal de una muestra de conveniencia de 220 pacientes ambulatorios que asistieron a la Facultad de Odontología de la Universidad de Antioquia Medellín-Colombia, entre el 30 de septiembre de 2015 y el 7 de septiembre de 2017. Intervenciones: no aplica. Medida principal de resultados: Síndrome de dolor miofascial.

Resultados: El 26,4\% de nuestra muestra presentó síntomas de MPS. Se encontró que más mujeres que hombres tenían MPS. El número de casos disminuye con la edad. El músculo más afectado es el trapecio, seguido del temporal, y no existen diferencias significativas en cuanto a estrato socioeconómico y ocupación. El síntoma asociado más frecuentemente informado es el dolor de cuello.

Conclusión: Debido a que existe una prevalencia tan alta, ya escala global, creemos que es importante establecer medios efectivos de diagnóstico y medidas adecuadas para la prevención y tratamiento de esta patología.

Palabras clave: Síndrome de dolor miofascial, prevalencia, punto gatillo.

\section{Resumo}

Objetivo: Diagnosticar a prevalência da Síndrome da Dor Miofascial (SDM) com relação ao sexo, idade, músculo acometido, estrato socioeconômico, ocupação e sintomas associados.

Métodos: Trata-se de um estudo transversal descritivo de uma amostra de conveniência de 220 pacientes ambulatoriais que compareceram à Faculdade de Odontologia da Universidade de Antioquia Medellín-Colômbia, entre 30 de setembro de 2015 e 7 de setembro de 2017. Intervenções: não aplicável. Principal medida de resultados: Síndrome da Dor Miofascial.

Resultados: 26,4\% da nossa amostra apresentou sintomas de MPS. Descobriu-se que mais mulheres do que homens tinham MPS. O número de casos diminui com a idade. 0 músculo mais acometido é o trapézio, seguido do temporal, e não há diferenças significativas em termos de estrato socioeconômico e ocupação. 0 sintoma associado relatado com mais frequência é a dor no pescoço.

Conclusão: Por ser uma prevalência tão elevada e em escala global, acreditamos ser importante estabelecer meios eficazes de diagnóstico e medidas adequadas para a prevenção e tratamento desta patologia.

Palavras-chave: Síndrome da Dor Miofascial, prevalência, ponto de gatilho. 


\section{Introduction}

Temporomandibular disorders (TMD) include a group of pathological conditions that affect the temporomandibular joint (both in its structure and function), as well as the head and neck muscles. One of these disorders is Myofascial Pain Syndrome (MPS), which is defined as a musculoskeletal disorder that presents sensory, motor, and autonomic symptoms produced mainly by active muscle trigger points. The manifested sensory disturbances are hyperalgesia, dysesthesia, and referred pain (1). It presents itself as regional pain of muscular origin, located in a muscle or muscle group. MPS has three components: a palpable band in the affected muscle, a trigger point, and the characteristic pattern of referred pain, which can produce distant effects, both motor and autonomic (2).

According to researchers Simons and Travell, MPS is the most frequent musculoskeletal condition, with an incidence of $54 \%$ in women and $45 \%$ in men (3). The most compromised age range is between 31 and 50 years, and the trapezius muscle the most often affected (4). The international prevalence is 13.5 to $47 \%$ (5). The definition of musculoskeletal pain, the different conditions included, and the age of populations studied are factors that cause variation in ranges of reported prevalence. Myofascial pain syndrome affects $85 \%$ of the population at some point in their lives $(6,7)$, and can affect any part of the body in 30-93\% of the population (6). The lack of unified criteria and diagnostic test make it very difficult to calculate its real prevalence. In Colombia, the epidemiology of TMD is not well-known, and is mostly limited to data obtained in the Third National Study of Oral Health, ENSAB III (1999), which reported a prevalence of symptoms of TMD of $47.4 \%$ in people over 15 years. However, the prevalence of MPS has not been established.

The diagnosis of MPS is based on meticulous exploration and clinical findings, mainly via manual location of the trigger point and identification of the reference zones. With myogenic TMD's, myofascial pain is the most frequently observed clinical symptom (Farella et al 2000).

This research is based on oral epidemiology, since the study of clinical disciplines, the knowledge of the prevalence and the etiology, all derived from epidemiological investigations, facilitates the diagnosis and prevention of the disease along with the formulation of new policies in public health. In addition, he points out, where a pathology has greater reach in a certain population and identifies the individuals at risk.

Currently, there is little research on this topic in South America; therefore, the objective of this research is to determine the prevalence of MPS, most commonly involving head and neck muscles, in a South American population. 


\section{Materials and methods}

This is a descriptive, cross-sectional study of a convenience sample of 220 out-patients who attended the Faculty of Dentistry of the Universidad de Antioquia Medellín-Colombia, between September 30 ${ }^{\text {th }}, 2015$ and the September $7^{\text {th }}, 2017$. The inclusion criteria were: patients attended in adult clinics, aged between 23 and 90 years, who voluntarily participated.

The exclusion criteria were the following: patients diagnosed with an associated rheumatic musculoskeletal pathology; patients diagnosed with a pathology of the cervical spine; those with a diagnoses of psychiatric disease and/or were in treatment; patients with diagnoses of craniofacial neurological diseases; patients with pain that requires analgesics and/or are being treated with adjuvant pharmacological management less than 48 hours before the measurement; and patients who have undergone orthognathic or cervical surgery less than 6 months before the measurement.

The initial assessment of each patient (identification, anamnesis, and associated symptoms) on the part of the principal investigator (PI) and co-investigators consisted of the collection of data by means of a format (available upon request) which produced reports for the possible diagnosis of MPS. Associated signs and symptoms were: tension headache, neck and back pain, pain in cheeks and face, sweating, tearing, coryza, excessive salivation, pilomotor activity, loss of balance, tinnitus, loss of motor coordination, sleep disorder, weakness of the compromised muscle, increased pain in the muscle in use, secondary hyperalgesia, protective co-contraction, and dryness of the eye.

Clinical examination and palpation were performed by the PI, who has experience in the management and diagnosis of MPS through clinical practice over 30 years. This evaluation tool was tested through a pilot test in 10 patients and allowed us to evaluate the internal consistency of the questionnaire and make adjustments for the field work.

The diagnosis of MPS was given following the criteria proposed by Simons et al.: presence of a myofascial trigger point (MTP), palpation tension and tense palpable band $(8,9)$, and referred pain $(8,10)$.

In the first step of classifying the MPS, with the patient at rest, the PI used manual palpation, which was performed with the palmar surface of the middle finger, using the index and the ring finger, to explore the adjacent areas, applying soft but steady pressure, so that the fingers compress the adjacent tissues in a slight circular motion. A single firm pressure of 2 seconds was applied. During the palpation, the patient was asked whether it hurt or not. If the answer was positive, the diagnosis of MPS was confirmed and recorded in an annex, specifying the most affected muscles 
in the head and neck. The muscles that were palpated are the following: occipitofrontal, temporal, masseter, mylohyoid, sternocleidomastoid, trapezius, elevator of the scapula, and splenium of the head.

The palpation was performed as follows: occipitofrontal - flat palpation of the muscle against the skull; temporal - flat palpation of this muscle, which is divided into anterior, middle, and posterior, each of which is palpated independently; anterior - palpated above the zygomatic arch and in front of the TMJ; medium - palpated above the TMJ and zygomatic arch; posterior - palpated above and behind the ear; masseter - flat palpation directly on the insertion of the body of the masseter, followed by clamp; mylohyoid - palpation of lower face and jaw and on caudal face; sternocleidomastoid - palpation in clamp done bilaterally, palpating down to its origin near the clavicle; scapula elevator - flat palpation; upper trapezius - flat palpation and clamp; and splenius of the head - flat palpation (11). All muscles were examined bilaterally.

The variables used were: sex, age (years completed); myofascial pain (yesno); associated symptoms (presence or not); type of muscle (name of the evaluated muscle); socio-economic stratum $(1,2,3,4,5,6)$; tense band (yes, no); trigger point (yes, no); and referred pain (yes, no).

The data collected in the respective questionnaires were digitized in a database on a spreadsheet in Excel and then imported into the statistical program SPSS version 20.0 (SPSS Inc., Chicago IL). Absolute and relative frequencies were used, the latter expressed as a percentage to obtain the prevalence of MPS, and the respective 95\% confidence intervals were calculated. Absolute and relative frequency distributions were also obtained to identify the most affected head and neck muscle in patients with MPS.

Additionally, Pearson's chi-square test was used to explore the association of MPS with sex and with age, the latter grouped into ranges according to their percentage distribution. The normality of the distribution was checked by the KolgomorovSmirnov test. The patients' ages were stated as the average and their respective standard deviations, in addition to the minimum and maximum values. The results were described in summary form by means of tables and graphs.

Patients diagnosed with MPS were notified of their pathology and immediately began the respective treatment.

This study was approved by the ethics committee of the Faculty of Dentistry (Act 07 of 2015) of the Universidad de Antioquia. All subjects signed an informed consent form for their participation. 


\section{Results}

A total of 220 patients admitted to the Faculty of Dentistry at the Universidad de Antioquia, met the criteria for inclusion and exclusion and were admitted for external consultation. The age range was between 23 and 89 years (89). $75 \%$ of the patients were female $(n=165)$ and $25 \%$ male $(n=55)$.

The results show that of the 220 patients, $26.4 \%(n=58)$ presented MPS in some or all of the muscles studied. Women presented significantly more MPS ( $p=$ 0.034) than men. (Graph I)

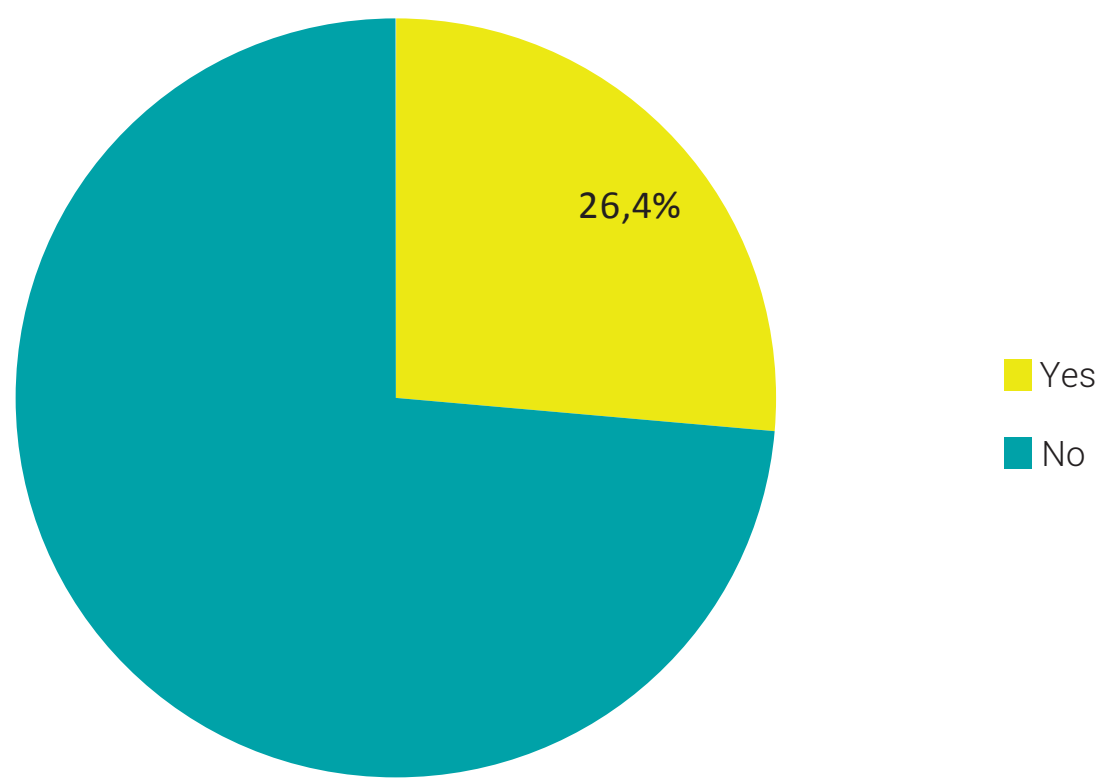

Graph I. Prevalence of myofascial pain syndrome Source: own work

With respect to age, the group with the highest prevalence of MPS was that of $<=34$ years $(60 \%)(n=6)$, with a significant difference of 0.006 between men and women.

There is no significant difference in terms of socio-economic stratum and occupation. The middle stratum presents the highest incidence of MPS at $30.9 \%$, and in relation to occupation, those from the "commerce and services" group show 28.6\%, followed by "housewives" with 28.2\%, and "unskilled manual labor" (27.8\%). (Table 1) 
Table 1. Prevalence of MPS in relation to age, socioeconomic stratum and occupation

\begin{tabular}{|c|c|c|c|c|c|c|c|c|c|c|c|c|}
\hline \multirow[b]{2}{*}{ Variables } & \multicolumn{4}{|c|}{ Men } & \multicolumn{4}{|c|}{ Women } & \multicolumn{4}{|c|}{ Total } \\
\hline & $\mathbf{N}$ & $\mathbf{n}$ & $\begin{array}{c}\mathbf{P} \\
(\%)\end{array}$ & p-valor & $\mathbf{N}$ & $\mathbf{n}$ & $\begin{array}{c}\mathbf{P} \\
(\%)\end{array}$ & p-valor & $\mathbf{N}$ & $\mathbf{n}$ & $\begin{array}{c}\mathbf{P} \\
(\%)\end{array}$ & p-valor \\
\hline \multicolumn{13}{|l|}{ Age } \\
\hline$\leq 34$ & 4 & 2 & 50.0 & \multirow{4}{*}{0.156} & 6 & 4 & 66.7 & \multirow{4}{*}{0.047} & 10 & 6 & 60.0 & \multirow{4}{*}{0.006} \\
\hline $35-54$ & 20 & 3 & 15.0 & & 79 & 28 & 35.4 & & 99 & 31 & 31.3 & \\
\hline $55-64$ & 13 & 2 & 15.4 & & 54 & 14 & 25.9 & & 67 & 16 & 23.9 & \\
\hline$\geq 65$ & 18 & 1 & 5.6 & & 26 & 4 & 15.4 & & 44 & 5 & 11.4 & \\
\hline
\end{tabular}

\section{Socioeconomic status}

\begin{tabular}{|c|c|c|c|c|c|c|c|c|c|c|c|c|}
\hline Low (1-2) & 27 & 4 & 14.8 & \multirow{3}{*}{0.837} & 79 & 20 & 25.3 & \multirow{3}{*}{0.227} & 106 & 24 & 22.6 & \multirow{3}{*}{0.186} \\
\hline Medium (3-4) & 26 & 4 & 15.4 & & 84 & 30 & 35.7 & & 110 & 34 & 30.9 & \\
\hline High (5- 6) & 2 & 0 & 0.0 & & 2 & 0 & 0.0 & & 4.0 & 0 & 0.0 & \\
\hline
\end{tabular}

\begin{tabular}{|c|c|c|c|c|c|c|c|c|c|c|c|c|}
\hline Occupation & & & & & & & & & & & & \\
\hline home & 1 & 0 & 0.0 & \multirow{5}{*}{0.881} & 109 & 31 & 28.4 & \multirow{5}{*}{0.658} & 110 & 31 & 28.2 & \multirow{5}{*}{0.643} \\
\hline professionals & 4 & 0 & 0.0 & & 5 & 2 & 40.0 & & 9 & 2 & 22.2 & \\
\hline $\begin{array}{l}\text { Business and } \\
\text { services }\end{array}$ & 12 & 2 & 16.7 & & 30 & 10 & 33.3 & & 42 & 12 & 28.6 & \\
\hline $\begin{array}{l}\text { Unskilled } \\
\text { manual labor }\end{array}$ & 22 & 4 & 18.2 & & 14 & 6 & 42.9 & & 36 & 10 & 27.8 & \\
\hline others & 16 & 2 & 12.5 & & 7 & 1 & 14.3 & & 23 & 3 & 13 & \\
\hline total & 55 & 8 & 145 & & 165 & 50 & 30.3 & - & 220 & 58 & 26.4 & 0.034 \\
\hline
\end{tabular}

$\mathrm{N}$ : total population at this age

n: number of people who have myofascial pain syndrome

Source: own work

Among the muscles examined, the upper trapezius presented the highest frequency of MPS in both men and women and affected $15 \%$ of patients ( $n=33$ ), representing the most affected muscle of all those studied, followed by the temporal in $10 \%$ of patients $(n=10)$. In Graph II, the frequencies of all muscles studied are shown. 
8 Prevalence of head and neck Myofascial Pain Syndrome in a South American population

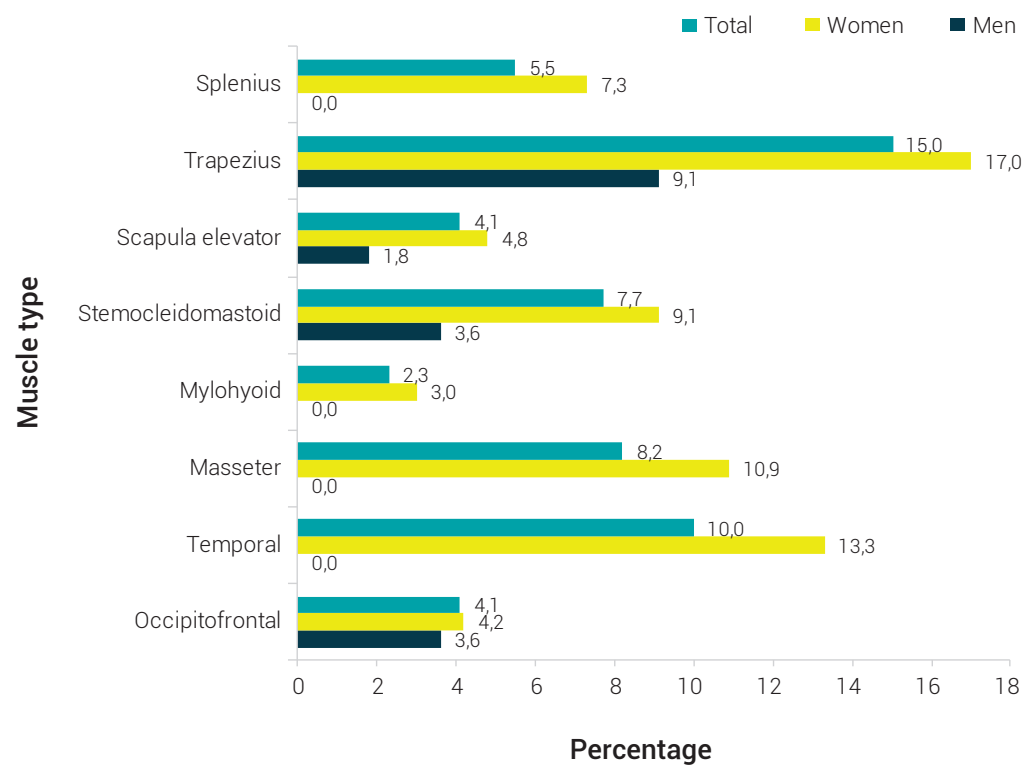

Graph II. Prevalence in different muscles examined

Source: own work

The highest prevalence of signs and symptoms associated with MPS was neck pain, seen in $53.6 \%$ of patients, seen more frequently in women at $54.5 \%$, followed by tinnitus in women at 47.3\%. (Graph III)

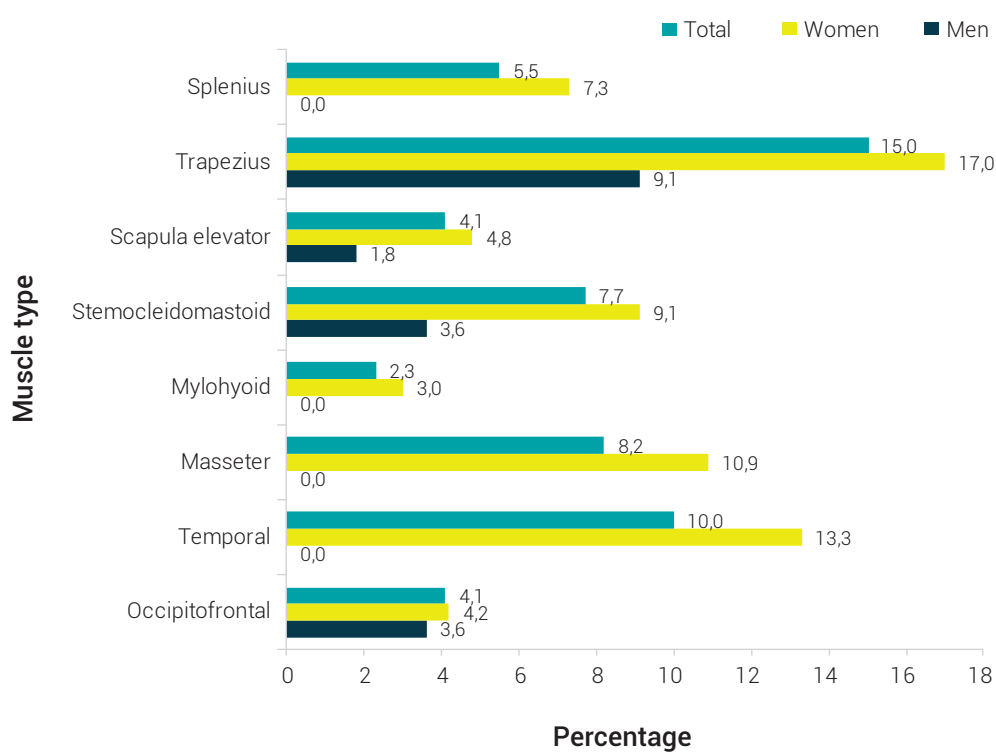

Graph III. Prevalence of signs and symptoms associated with MPS Source: own work 


\section{Discussion}

In pain units it is estimated that between 30 and $85 \%$ of patients came for treatment of myofascial pain (12). The international prevalence is 13.5 to $47 \%(7,13)$. The prevalence of MPS in this research was $26.4 \%$, showing a decrease as age increases. This data is in agreement with those reported in studies of international prevalence.

In research by Iturriaga et al., it was found that age was not an associated factor ( $p=0.396)$, unlike sex, where women presented significantly more MPS ( $p=0.043)$. In our research, we found a concordance with respect to sex, but in other studies, the difference is not statistically significant (Okeson, Simons et al.) $(14,15)$.

Regarding age, some sources have reported that the appearance of MPS is more frequent in subjects between 27.5 and 50 years old. This does not coincide with our research, which found that the most frequent age in which MPS occurs is equal to or less than 34 years.

When looking at the patients in our study affected by MPS, a high prevalence was observed in all muscles studied, being lower in the mylohyoid and higher in the trapezium, which is in agreement with Fernández-de-las-Peñas et al. (16), but differs with the investigation by Iturriaga et al. (2014), in which the least affected muscle was the sternocleidomastoid and the one with the highest prevalence was seen in the masseter.

According to studies by Fernández-de-las Peñas et al., 2007, and Alonso-Blanco et al. 2011, the most common symptomatology associated with MPS is tension-type headache. In this study, the greatest associated symptomatology was neck pain, coinciding with the research of Lluch E et al (17) and Cerezo-Téllez E et al $(18,19)$. Our study seems to support a correlation between neck pain and the upper trapezius muscle, since the muscles can refer pain to the area of the posterior neck (20).

High prevalence of MPS has been found in patients with mechanical neck pain, whiplash injuries, cervicogenic headache, and fibromyalgia, $(14,21,22)$ which, considering the large number of work absences and disability that it produces in patients (1), makes the study of MPS even more important.

One of our conclusions was that MPS decreases with age, which is not in agreement with the research of Gerwin RD (19), in which the prevalence of this syndrome increased with age.

The diagnosis of trigger points is actually one of the limitations of our study since there are no certified diagnostic criteria for the identification of these points (23), although the diagnostic guides used in our study are commonly used with the vast majority of patients, scientific studies, and clinical practices. The examiner of our 
study was a fully-qualified, trained dentist with more than 30 years of experience in the diagnosis and treatment of myofascial pain.

The lack of codified criteria, uniform diagnoses based on international multicenter studies (12), and the absence of a diagnostic test made it difficult to calculate the prevalence of MPS $(8,24)$.

It could be considered a limitation of our research that we may have introduced a potential bias since the data was collected by only one examiner. We recommend consideration of the possibility having several examiners, which unfortunately was not feasible in our study.

Pain is a confusing phenomenon composed of multiple factors and depends on the interaction of biopsychosocial factors, which includes physical, behavioral, cognitive, emotional, spiritual, and interpersonal aspects $(23,25)$. The concept that treatment of chronic pain is a fundamental human right (26) and a concern of public health must be considered due to its prevalence and economic-social cost, and because it produces large numbers of work absences and incapacities $(28,29)$.

Another limitation in this study was the fact that we did not follow up on all patients diagnosed and treated with myofascial pain syndrome.

Given that MPS is a commonly-diagnosed pathology with a great impact on the quality of life of patients, it represents an important public health problem ${ }^{29}$ that justifies the need to establish prevention, detection, evaluation, and treatment programs (2).

It is of critical importance to implement prevention programs for MPS by monitoring cases and intervening in the management of conditions in workplaces and the biomechanical risk factors of occupational areas. Follow up is also necessary in order to perform early interventions and make the necessary corrective measures for each of the patients involved.

\section{Conclusions}

In this study, the prevalence of MPS is high among patients with temporomandibular disorders. The prevalence of MPS in this research was $26.4 \%$, showing a decrease as age increases.

Women have a higher prevalence of MPS and the most frequent age in which this syndrome is found, is equal to or less than 34 years.

The most common symptoms associated with MPS is headache and the most affected muscle is the upper trapezius. 


\section{References}

1. Lavelle W, Smith HS. Myofascial trigger points. Anesthesiol Clin N Am. Lavelle ED, 2007: 841851. doi: 10.1016 / j.anclin.2007.07.003

2. Cerezo-Téllez E, Torres-Lacomba M, Mayoral-Del Moral et al. Prevalence of Myofascial Pain Syndrome in Chronic Non-Specific Neck Pain: A Population-Based Cross-Sectional Descriptive Study. Pain Med 2016; 17(12):2369-2377. doi: 10.1093 / pm / pnw114

3. Wright, EF. Referred craniofacial pain patterns in patients with temporomandibular disorder. J. Am. Dent. Assoc. 2000; 131 (9): 1307- 15. doi: 10.14219 / jada.archive.2000.0384

4. Davidoff R. Trigger points and myofascial pain: toward understanding how they affect headaches. Cephalalgia. 1998; 18(7):436-448.

5. Cimmino MA, Ferrone C, Cutolo M. Epidemiology of chronic musculoskeletal pain. Best Pract Res Clin Rheumatol. 2011; 25:173- 183. doi: 10.1016 / j.berh.2010.01.012

6. Staud R. Future perspectives: pathogenesis of chronic muscle pain. Best Pract Res Clin Rheumatol. 2007; 21:581- 596. doi: 10.1016/ j.berh.2007.02.013

7. Simons DG. Clinical and etiological update of miofascial pain from trigger points. J Musculoskelet Pain. 1996; 4:93-122.

8. Simons DG, Travell JG, Simons LS. Dolor y disfunción miofascial. Tomo 1. El manual de los puntos gatillo. Mitad superior del cuerpo. $2^{\text {a }}$ ed. Madrid: Editorial Médica Panamericana, 2002.

9. Simons DG. Diagnostic criteria of myofascial pain caused by trigger points. J Musculoskelet Pain. 1999; 7(1/2):111-20.

10. Travell J, Rinzler SH. The myofascial genesis of pain. Postgrad Med. 1952; 11(5):425-34.

11. Muscolino, J E. Manual de Palpación Ósea y Muscular. Con puntos gatillo, patrones de referencia y estiramientos. 2a ed. Madrid: Ed Panamericana, 2014.

12. Díaz, M. Cervicalgia miofascial. Rev. Med. Clin. Condes. 2014; 25(2): 200-208. doi: 10.1016/ S0716-8640(14)70031-8

13. Villaseñor J, Escobar V, De la Lanza, L. et al. Síndrome de dolor miofascial. Epidemiología, fisiopatología, diagnóstico y tratamiento. Rev. Esp. Méd. Quir. 2013; 18: 148-157. 
14. Murillo,JP, Alpizar DE. Síndrome Miofascial. Medicina Legal de Costa Rica. 2016; 33 (1).

15. Uturriaga V, Bornhardt T, Hermosilla L et al. Prevalencia de dolor miofascial en músculos de la masticación y cervicales en un centro especializado en trastornos temporomandibulares y dolor orofacial. Int. J. Odontostomat. 2014; 8(3): 413-417. doi: http://dx.doi.org/10.4067/ S0718-381X2014000300015

16. Fernández-de-las- Peñas $C$ et al. Myofascial trigger points and their relationship to headache clinical parameters in chronic tension-type headache. Headache. 2006; 46(8): 1264-72. doi: 10.1111 / j.1526-4610.2006.00440.x

17. Lluch E, Nijs J, De Kooning M et al. Prevalence, Incidence, Localization, and Pathophysiology of Myofascial Trigger Points in Patients with Spinal Pain: A Systematic Literature Review. J Manipulative Physiol Ther. 2015; 38(8):587-600. doi: 10.1016 / j.jmpt.2015.08.004

18. Cerezo-Téllez E et al. Effectiveness of dry needling for chronic nonspecific neck pain: a randomized, single-blinded, clinical trial. Pain. 2016; Sep; 157(9):1905-17. doi: 10.1097 / j.pain.0000000000000591

19. Gerwin RD. Classification, epidemiology, and natural history of myofascial pain syndrome. Current pain and headache. 2001; 5(5): 412-420. doi: 10.1007 / s11916-001-0052-8

20. Simons DGTravell JGSimons LS. Dolor miofascial y disfunción. El Manual de Trigger Point. Mitad superior del cuerpo. 2da edición. Baltimore, MD: Williams y Wilkins, 1999.

21. Fernandez-de-la-Peña, $C$ et al. The role of myofascial trigger points in musculoskeletal pain syndromes of the head and neck. Curr Pain Headache Rep. 2007; 11(5):365-72. doi: 10.1007 / s11916-007-0219-z

22. De-la-Llave-Rincón A et al. Myofascial trigger points in the masticatory muscles in patients with and without chronic mechanical neck pain. J. Manipulative Physiol. Ther. 2012; 35(9):67884. doi: 10.1016 / j.jmpt.2012.10.008

23. Simons DG. Revisión de MTrPs enigmáticos como causa frecuente de dolory disfunción musculoesqueléticos enigmáticos. J Electromyogr Kinesiol. 2004; 14(1): 95-107.

24. Chiarotto A, Clijsen R, Fernandez-de-Las-Peñas C et al. Prevalence of Myofascial Trigger Points in Spinal Disorders: A Systematic Review and Meta-Analysis. Arch Phys Med Rehabil. 2016; 97(2):316-37. doi: 10.1016 / j.apmr.2015.09.021 
25. Riihimäki H, Viikari-Juntura E. Sistema musculoesquelético. Enciclopedia de Salud y Seguridad en el trabajo. 3a ed. Madrid: Gestión editorial Chantal Dufresne, BA; 1998. Cap 6.

26. Álvarez B, Alonso JL, Alegre J. The pathophysiology of pain the fibromyalgia syndrome: at the threshold of understanding. Med Clin (Barc). 1999; 12: 621-630.

27. Restrepo D, Silva I Relación entre el ausentismo laboral y los síntomas músculo-esqueléticos en trabajadores de la salud de una institución prestadora de servicios de salud sexual y reproductiva. Revista Medicina. 2014; 36 (1): 45-55.

28. Casas Sánchez, AS, Patiño Segura, MS. Prevalencia y factores asociados con el dolor de espalda y cuello en estudiantes universitarios. Revista de la Universidad Industrial de Santander. Salud [Internet]. 2012; 44(2):45-55.

29. Valmaseda, E, Gay E, Cosme. Diagnóstico y tratamiento de la patología de la articulación temporomandibular. 2002; 29(2): 55-70 